\title{
Preparing for English at Work: Intercultural Communicative Competence in Language Education
}

\author{
Kelly Kimura, Editor-in-Chief \\ Soka University, Tokyo
}

The advancement of globalization, the upcoming Association of Southeast Asian Nations (ASEAN) economic integration, the ongoing negotiations for major free trade agreements involving all countries within the Asian region, and the institutions, companies, and individuals involved rely on successful communication across borders. Although English cannot always be - and should not be presumed to be - the lingua franca for any given multilingual context (Kubota, 2013; Kubota \& McKay, 2009; Matsuda \& Friedrich, 2011) in Asia, it is often the language chosen. The choice of English as a lingua franca (ELF) is exemplified by ASEAN's decision to use English as the working language of the association (Association of Southeast Asian Nations, 2007) and by companies' increasing use of the language for international and internal business communication. While English has long been often used for international meetings, some Asia-based companies, such as Nissan, Rakuten, Fast Retailing, Bridgestone, and Samsung (Mukai, 2013; Neeley, 2012), have adopted English throughout their organizations. The use of English for communication is not limited to employees of multinational or major domestic companies. With tourism reaching more remote areas and the rising mobility of students and workers in the region, service employees may at times need to communicate with customers using the shared knowledge they have of a language, which may often be English (Yoneoka, 2011). Additionally, English may be necessary to access information for workers in many jobs (Frazier, 2012; Louhiala-Salminen \& Kankaanranta, 2012). Furthermore, even when spoken communication is in another language, written communication may be required to be in English (Evans, 2013).

As non-native speakers of English are increasingly involved in business transactions with each other, more attention is being paid to how English is used as a lingua franca in the business domain. According to Kankaanranta and Louhiala-Salminen (2013), English as a business lingua franca (BELF) focuses on achieving successful communication; however, while intelligibility is important, fluency and linguistic accuracy are not. As with ELF, language is used as a code which does not require understanding of its native-speaking cultures; in effect, it does not belong to any particular group; instead, it is informed by the cultures and languages of its users and thus becomes everyone's language (Kankaanranta \& Louhiala-Salminen, 2013). As Canagarajah (2007, p. 926) noted, "LFE [lingua franca English] does not exist as a system 'out there.' It is constantly brought into being in each context of communication." BELF retains these qualities of context-dependency and fluidity (Kankaanranta \& Louhiala-Salminen, 2013).

Language Education in Asia, 2013, 4(2), 104-109. http://dx.doi.org/10.5746/LEiA/13/V4/I2/A01/Kimura 
In international business contexts where both parties are non-native speakers of English, a high level of proficiency in English is not necessary to communicate successfully (Kankaanranta \& Louhiala-Salminen, 2013; Kubota, 2013). While language knowledge and field-specific vocabulary are required (Kankaanranta \& Louhiala-Salminen, 2013), proficiency in English matters less than expertise in the field in question (Kubota, 2013; VanderMey, 2013). Skill in using strategies to overcome communication problems and understanding and respect of the cultures of the people involved are essential; together with language knowledge and business expertise, these qualities can lead to intercultural communicative competence "sufficient for getting the work done and creating rapport" (Kankaanranta \& Louhiala-Salminen, 2013, p. 27).

As McKay (2003) pointed out, when English is used as an international language, pedagogy "must consider the specific goals that lead learners to study English and not assume that these goals necessarily involve attaining full proficiency in the language" (p. 5). Kubota (2013) commented that "the blurred definition of language proficiency for business purposes calls into question the appropriateness of conventional goals for teaching foreign languages" (para. 31). With the increasing use of a fluid, situation-specific English by non-native speakers of varying levels of proficiency with their counterparts from different cultures, having intercultural communicative competence as a goal instead of native-speaker-like proficiency may better prepare our students to join the globalized business community. English is a tool, and intercultural communicative competence is what will allow our students to use that tool well in context-appropriate ways without requiring an advanced language proficiency level. In this brief note, just two aspects of successful communication in international business contexts that language educators may want to consider adding in more depth to their classes will be discussed: communication strategies and intercultural awareness.

Preventing or overcoming problems in communication is crucial in business: failure or avoidance of communication can have a negative impact in such areas as collaboration (Neeley, Hinds, \& Cramton, 2012), relationships, and reputation (Louhiala-Salminen \& Kankaanranta, 2012). Accommodation strategies to facilitate communication should be explicitly taught with ample opportunity given for practice. Critical strategies include using context to obtain meaning, requesting clarification to obtain meaning, restating to clarify meaning, self-repairing to clarify meaning, using circumlocution, summarizing, using examples, and supplementing spoken communication with gestures and other non-verbal means (Kaur, 2011; Kubota, 2013; Matsuda \& Friedrich, 2011). These practical strategies are employed in business situations as more employees are expected to effectively communicate in a language in which they and / or their interlocutors may not be highly proficient. Taking the strategy of supplementing spoken communication as an example shows practices that are as varied as the contexts. In training Thai employees about the production process and technical skills for a new factory, Japanese employees supported their explanations with charts and demonstrations (Sakai, 2013). Service workers in Japan in Yoneoka's (2011) study used maps, menus, and other items at hand to communicate with customers from other countries. A professional in Hong Kong reported that difficulties in understanding different English varieties were minimized by the provision of agendas and other necessary information to participants in advance of international meetings (Evans, 2013). Overall, the use of communication strategies can demonstrate the speaker's hope for a successful interaction and may help to build rapport with the interlocutor (Yoneoka, 2011).

Intercultural knowledge and understanding are also essential for successful business communication. According to Matsuda and Friedrich (2011), students should learn that English varietal differences go well beyond pronunciation and include values related to culture, language, and other factors. Students, who may have little experience outside their own 
cultures, will benefit from gaining an awareness of cultural variations in communication styles (Kankaanranta \& Louhiala-Salminen, 2013) and behaviors, as well as receiving opportunities to explore or even adjust their own when appropriate. For example, Du-Babcock (2013) found that in international meetings, Asian participants from Hong Kong and Japan took significantly fewer turns in speaking than their European counterparts from Finland and Sweden; instruction and practice could be given in turn-taking skills to address what may appear to be a shortcoming in participation in such meetings. Understanding that the international business community has its own culture is also necessary; being clear, concise, direct, and courteous (Kankaanranta \& Louhiala-Salminen, 2013; Kubota, 2013), and having the ability to evaluate a situation to employ the most suitable medium, timing, focus, and style of communication for a particular audience in spoken and / or written communication (Kankaanranta \& LouhialaSalminen, 2013) are expected. Overall, students should be taught to objectively examine and understand their own cultures and the cultures they may have contact with; for an approach, see the plenary paper in this issue.

More research on English as a lingua franca in the workplace in Asia is necessary, including field research on the communication requirements for real business situations (Du-Babcock, 2012) and action research by teachers so that changes are suitable for their particular contexts can be determined (Jenkins, Cogo, \& Dewey, 2011). In the meantime, teaching students communication strategies and intercultural understanding to more successfully use the English they are learning will begin to develop their intercultural communicative competence. Suggestions for effective classroom practice include those that can simulate intercultural business situations in some way, such as problem-based learning or case studies (Kankaanranta \& Louhiala-Salminen, 2013); outside the classroom, internships in multinational companies and study abroad experience can help students to further improve (Du-Babcock, 2012). Possessing intercultural communicative competence may be of benefit for many high school and university students and current employees to be more prepared for the upcoming employment and business opportunities and challenges in the region.

Volume 4, Issue 2 begins with a paper from Richmond Stroupe, the plenary speaker at the $9^{\text {th }}$ CamTESOL Conference. In looking at the necessary qualities that students will need to compete in an increasingly globalized market, he explains strengths other than language proficiency that language educators can develop in their students and describes programs where these qualities have been successfully developed.

The research section begins with an investigation by Simon Smith and Nicole Keng into the acquisition of Graeco-Latin origin words by three learner groups, each with different L1s containing differing levels of these words. The results offer insights for EAP instructors teaching academic English vocabulary, which is mainly of Graeco-Latin origin. In the second article, Chun-Chun Yeh examines the learning experiences and views of students regarding a podcast learning project for extensive listening. Students were provided scaffolding to achieve autonomy in choosing existing podcast resources for meaningful listening practice. The results reveal factors that were challenging and those that enhanced the learners' experience with the project.

In the teaching practice section, Asako Takaesu shows how TED Talks can be used as extensive listening assignments for upper-intermediate and intermediate level students. She further discusses ways to support lower-proficiency learners so that they may benefit from extensive listening. In the next paper, Oana Cusen explains how a project on child soldiers was designed and then successfully implemented in a high school English curriculum by using a projectbased teaching and learning framework. Clear steps to teacher-supported learner autonomy 
culminate in a poster presentation on a topic related to the project theme. In the third teaching practice paper, James Dunn advocates making use of students' semantic networks for more effective vocabulary learning. Providing students with opportunities to connect new words to their prior knowledge and experience makes the words meaningful to them. The issue concludes with a paper from Tim Marchand and Benedict Rowlett. By using digital media to deliver news articles and materials and to create a forum for their learners to express their views, they encouraged learner engagement in the course content outside of the classroom.

I would like to extend my deep appreciation to the members of the Advisory Board and the Editorial Board for their ongoing support of Language Education in Asia. We rely on the eyes of our Editorial Board for papers that offer practical recommendations for teachers in the region and are of interest internationally as well. The insightful comments from the Editorial Board contribute to the professional growth of those who submitted papers as educators, researchers, and authors.

Many thanks go to the Volume 4, Issue 2 editorial team, veteran Assistant Editor Deborah Sin and new Assistant Editor Keuk Chan Narith, Managing Editor Phanisara (Nina) Logsdon, and our new Editorial Assistant Visoth Nob, all of whom kept the publication process on track despite their already demanding regular work.

Thank you also to all of the authors who submitted papers for consideration for Volume 4, and congratulations to the authors whose papers are published in this issue. Your contributions to the body of knowledge in your areas of language education are much appreciated.

We continue to encourage submissions, particularly from regional and international authors working in the development context.

Finally, this issue is dedicated to the memory of Kevin Cleary, Japan Association for Language Teaching (JALT) President and a member of the LEiA Editorial Board. Kevin passed away unexpectedly and too young on January $16^{\text {th }}, 2014$. 


\section{References}

Association of Southeast Asian Nations. (2007). The ASEAN charter. http://www.asean.org/archive/publications/ASEAN-Charter.pdf

Canagarajah, S. (2007). Lingua franca English, multilingual communities, and language acquisition. The Modern Language Journal, 91, 923-939. http://dx.doi.org/10.1111/j.1540-4781.2007.00678.x

Du-Babcock, B. (2012). Development of English for business and professional communication in Asia: A revisit of BELF in the Asian environment. Language Learning Technologies, 2(1), 7-30. Retrieved from http://apamall.com/asapro/journal/Vol2_No1/Article_1_Bertha_Du-Babcock.pdf

Du-Babcock, B. (2013). English as Business Lingua Franca: A comparative analysis of communication behavior and strategies in Asian and European contexts. Iberica, 26, 99130.

Evans, S. (2013). Perspectives on the use of English as a business lingua franca in Hong Kong. Journal of Business Communication, 50(3), 227-252. http://dx.doi.org/10.1177/0021943613487073

Frazier, D. (2012, June 20). English lessons. Forbes Asia. Retrieved from http://www.forbes.com/sites/donaldfrazier/2012/06/20/english-lessons/

Jenkins, J., Cogo, A., \& Dewey, M. (2011). State-of-the-art article: Review of developments in research into English as a lingua franca. Language Teaching, 44(3), 281-315. http://dx.doi.org/10.1017/S0261444811000115

Kankaanranta, A., \& Louhiala-Salminen, L. (2013). "What language does global business speak?" - The concept and development of BELF. Iberica, 26, 17-34.

Kaur, J. (2011). Raising explicitness through self-repair in English as a lingua franca. Journal of Pragmatics, 43, 2704-2715. http://dx.doi.org/10.1016/j.pragma.2011.04.012

Kubota, R. (2013). 'Language is only a tool': Japanese expatriates working in China and implications for language teaching. Multilingual Education, 3:4. http://dx.doi.org/10.1186/2191-5059-3-4

Kubota, R., \& McKay, S. (2009). Globalization and language learning in rural Japan: The role of English in the local linguistic ecology. TESOL Quarterly, 43(4), 593-619.

Louhiala-Salminen, L., \& Kankaanranta, A. (2012). Language as an issue in international internal communication: English or local language? If English, what English? Public Relations Review, 38, 262-269. http://dx.doi.org/10.1016/j.pubrev.2011.12.021

Matsuda, A., \& Friedrich, P. (2011). English as an international language: A curriculum blueprint. World Englishes, 30(3), 332-344. http://dx.doi.org/10.1111/j.1467971X.2011.01717.x

McKay, S. (2003). Toward an appropriate EIL pedagogy: Re-examining common ELT assumptions. International Journal of Applied Linguistics, 13(1), 1-22. http://dx.doi.org/10.1111/1473-4192.00035

Mukai, A. (2013, October 17). Bridgestone adopts English as official language in global push. Bloomberg. http://www.businessweek.com/news/2013-10-17/bridgestone-adoptsenglish-as-official-language-in-global-push

Neeley, T. (2012, May). Global business speaks English [Executive Summary]. Harvard Business Review: The Magazine. Retrieved from http://hbr.org/2012/05/global-businessspeaks-english/ar/1

Neeley, T. B., Hinds, P. J, \& Cramton, C. D. (2012). The (un)hidden turmoil of language in global collaboration. Organizational Dynamics, 41(3), 236-244. http://dx.doi.org/10.1016/j.orgdyn.2012.03.008

Sakai, K. (2013, December 12). Bottling the magic. Nikkei Asian Review. p. 10-13.

VanderMey, A. (2013, October 16). Hire the local, not the expat. Fortune. Retrieved from http://management.fortune.cnn.com/2013/10/16/ellen-kullman-mpw/ 
Yoneoka, J. (2011). The importance of language negotiation in initial intercultural encounters: The case of the service industry employee. Intercultural Communication Studies, 20(1), 90-103. Retrieved from

http://www.uri.edu/iaics/content/2011v20n1/08JudyYoneoka.pdf 